\title{
Chemical compositions of the essential oil and calculation the biophysicochemical coefficients of the components of Hymenocrater longiflorus Benth. of Iran
}

\author{
Avat (Arman) Taherpour ${ }^{1^{*}}$, Hossein Maroofi ${ }^{2}$, Mahdi Changizi ${ }^{3}$, Reza Vafaei Shoushtari ${ }^{3}$, \\ Kambiz Larijani ${ }^{4}$, Azadeh Kazempour ${ }^{1}$ \\ ${ }^{1}$ Chemistry Department, Graduate School, Islamic Azad University, Arak Branch, Arak, Iran; *Corresponding Author: \\ avatarman.taherpour@gmail.com, a.taherpour@iau-arak.ac.ir \\ ${ }^{2}$ Research Center of Agriculture \& Natural Resources, Forked Road of Jame-Jam, Sanandaj, Iran \\ ${ }^{3}$ Faculty of Agriculture, Islamic Azad University, Arak Branch, Arak, Iran \\ ${ }^{4}$ Research Council of Science and Research Campus, Islamic Azad University, Tehran, Iran
}

Received 8 December 2010; revised 10 January 2011; accepted 12 January 2011.

\begin{abstract}
The volatile constituents of the essential oil of Hymenocrater longiflorus Benth. growing wild in Kurdistan-Iran were investigated using the GC and GC/MS techniques. Fifteen compounds, representing twenty $(\mathbf{9 7 . 0 3 \% )}$ of the total oil were identified. The main components were: $\alpha$ Pinene $(22.47 \%), \beta$-Caryophyllene (18.05\%), $\beta$ Eudesmol $(14.92 \%)$, $\alpha$-Copaene $(9.84 \%)$, $\mathrm{y}$-Elemene $(6.79 \%)$, $\delta$-Cadine-ne $(6.13 \%)$, (-)Bornyl acetate $(5.61 \%)$, $\alpha$-Amorphene $(3.84 \%)$, $\alpha$-Fenchyl acetate $(2.35 \%)$ and $\beta$-Pinene $(2.07 \%)$. Some of the physicochemical properties like the logarithm of calculated Octanol-Water partitioning coefficients $\left(\log K_{o w}\right)$, total biodegradation and ( $\mathrm{TB}_{\mathrm{d}}$ in $\mathrm{mol} / \mathrm{h}$ and $\left.\mathrm{gr} . / \mathrm{h}\right)$, water solubility $\left(S_{w}, m g \cdot L^{-1}\right.$ at $\left.25^{\circ} \mathrm{C}\right)$ and median lethal concentration $50\left(L_{50}\right)$ were calculated for the $15 \mathrm{com}$ ponents of Hymenocrater longiflorus Benth.
\end{abstract}

Keywords: Hymenocrater longiflorus Benth.; Essential Oil Compounds; Hydro Distillation; $\alpha$-Pinene; $\beta$-Caryophyllene; $\beta$-Eudesmol; $\alpha$-Copaene; Octanol-Water Partitioning; Total Biodegradation; LC 50 ; Gas Chromatography; Mass Spectroscopy

\section{INTRODUCTION}

Hymenocrater genus has over 21 species in the world. $[1,2]$ The Hymenocrater longiflorus Benth. materials of this study were collected from west of Iran (from the mountains area, altitude $1550-1800 \mathrm{~m}$, in front of the Dezlie village-Marivan-Kurdistan province of Iran) at the
Jun. 2008. A voucher specicum has been deposited in herbarium of Research Center of Agriculture \& Natural Resources, Sanandaj-Kurdistan, Iran (Herbarium ID: 447898-1).

This herb was firstly nominated by G. Bentham in 1848. The local name of Hymenocrater longiflorus Benth., is Soor-Halale (Sỏor-HALALE). The other names of this herb are: Gole Arvaneh-Avarmani and SoorSanduo. The Hymenocrater longiflorus Benth. was utilized as a medicinal herb in local and traditional medicine (in Kurdistan). From the aerial parts of this herb in crude or baked form was utilized as an anti-inflammatory, sedative, anti-skin allergic reaction (for skin diseases and insect bite) by folks in local medicine.

The octanol-water partition coefficient $\left(K_{o w}\right)$ is a measure of the equilibrium concentration of a compound between octanol and water that indicates the potential for partitioning in to soil organic matter (i.e., a high $K_{o w}$ indicates a compound which will preferentially partition into soil organic matter rather than water). This coefficient is inversely related to the solubility of a compound in water. The $\log K_{\text {ow }}$ is used in models to estimate plant and soil invertebrate bioaccumulation factors. This parameter is also used in many environmental studies to help determine the environmental fate of chemicals [3-5].

Biodegradation is usually quantified by incubating a chemical compound in presence of a degrader, and measuring some factors like oxygen or production of $\mathrm{CO}_{2}$. The biodegradation studies demonstrate that microbial biosensors are a viable alternative means of reporting on potential biotransformation. However, a few chemicals are tested and large data sets for different chemicals need for quantitative structural relationship studies [6].

$\mathrm{An} \mathrm{LC}_{50}$ value is the concentration of a material in air 
that will kill $50 \%$ of the test subjects (animals, typically mice or rats) when administered as a single exposure (typically 1 or 4 hours). Also called the median lethal concentration and lethal concentration 50, this value gives an idea of the relative acute toxicity of an in halable material. Typical units for $\mathrm{LC}_{50}$ values are parts per million $(\mathrm{ppm})$ of material in air, $\mu \mathrm{g}$ (micrograms, $10^{-6}$ gram) per liter of air and milligrams $\left(10^{-3}\right.$ gram $)$ per cubic meter of air [7].

\section{ANALYTICAL METHODS}

Dried aerial parts of Hymenocrater longiflorus Benth. were subjected to hydrodistillation for 5 hours using Clevenger-type apparatus to produce a yellow oil in $0.28 \%$ (w/w) yield. The essential oil of the aerial parts of $H y$ menocrater longiflorus Benth. was examined by GC/MS (GC: HP 6890, MS: HP 5973), column (HP5-MS, $30 \mathrm{~m}$ $\times 0.25 \mathrm{~mm}$ fused silica capillary column, film thickness $0.32 \mu \mathrm{m})$ by temperature program $60^{\circ} \mathrm{C}(3 \mathrm{~min})-210^{\circ} \mathrm{C}$ (2 min) at the rate of $6^{\circ} \mathrm{C} / \mathrm{min}$ (injection temperature $250^{\circ} \mathrm{C}$, carrier gas: helium (with purity $99.999 \%$ ), detector temperature $150^{\circ} \mathrm{C}$, ionization energy in mass was $70 \mathrm{eV}$, mass range 10-300 amu, and scan time was $1 \mathrm{sec}$.

The list of identified components is presented in Table 1 . The constituents were identified by comparing their MS spectra with those in computer library or with authentic compounds. The identifications were confirmed by comparison of their retention indices either with those of authentic compounds or with data in the literature [8-10]. In the aerial parts of Hymenocrater longiflorus Benth. the major identified components and the relative amounts based on peak area were: $\alpha$-Pinene $(22.47 \%), \quad \beta$-Caryophyllene $\quad(18.05 \%), \quad \beta$-Eudesmol (14.92\%), $\alpha$-Copaene $(9.84 \%), \gamma$-Elemene $(6.79 \%), \delta$ Cadinene $(6.13 \%),(-)$ Bornyl acetate $(5.61 \%), \alpha-$ Amorphene (3.84\%), $\alpha$-Fenchyl acetate $(2.35 \%)$ and $\beta$ Pinene $(2.07 \%)$.

The calculated data of the Octanol-Water partitioning coefficients $\left(\log K_{o w}\right)$ and the total biodegradation $T B_{d}$ (in $\mathrm{mol} / \mathrm{h}$ and $\mathrm{gr} / \mathrm{h}$ ), water solubility $\left(S_{w}, \mathrm{mg} \cdot \mathrm{L}^{-1}\right.$ at $25^{\circ} \mathrm{C}$ ) and median lethal concentration $50\left(\mathrm{LC}_{50}\right)$ were calculated by the EPI-suit v4.00 package [11].

\section{DISCUSSION}

Some of the plants from genus Hymenocrater have been previously studied, but there are rare studies of the chemical composition of essential oil of plants from genus Hymenocrater. This study elaborates upon the volatile constituents of the essential oil of Hymenocrater longiflorus Benth. growing wild in Kurdistan-Iran were investigated by GC and GC/MS technique. As could see in Table 1, $\alpha$-Pinene (22.47\%), $\beta$-Caryophyllene (18.05\%) (trans-Caryophyllene) and $\beta$-Eudesmol (14.92\%) have the high percentages (about 55.44\%) among the fifteen components that were identified. Some other components, i.e. $\alpha$-Copaene $(9.84 \%), \gamma$-Elemene $(6.79 \%), \delta$ -

Table 1. Essential oil constituents, logarithm of calculated Octanol-Water partitioning coefficients $\left(\log K_{o w}\right)$, total biodegradation and $\left(T B_{d}\right.$ in $\mathrm{mol} / \mathrm{h}$ and $\left.\mathrm{gr} . / \mathrm{h}\right)$, water solubility at $25^{\circ} \mathrm{C}(\mathrm{mg} / \mathrm{L})$ and median lethal concentration $50\left(\mathrm{LC}_{50}\right)$ of Hymenocrater longiflorus Benth. of Iran.

\begin{tabular}{|c|c|c|c|c|c|c|c|c|c|}
\hline \multirow{2}{*}{ No } & \multirow{2}{*}{$\begin{array}{l}\text { Name of } \\
\text { Compound }\end{array}$} & \multirow{2}{*}{ K. I.* } & \multirow{2}{*}{$\mathrm{RT}^{* *}$} & \multirow{2}{*}{$\%$} & \multirow{2}{*}{$\log K_{o w}{ }^{a}$} & \multirow{2}{*}{$\begin{array}{l}\text { Water Solubility } \\
\text { at } 25^{\circ} \mathrm{C}(\mathrm{mg} / \mathrm{L})\end{array}$} & \multirow{2}{*}{$\begin{array}{c}\mathrm{LC}_{50}(\text { in } \mathrm{mg} / \mathrm{L} \\
\text { or ppm) }\end{array}$} & \multicolumn{2}{|c|}{ Total Biodegradation } \\
\hline & & & & & & & & $\mathrm{mol} / \mathrm{h} \times 10^{-5}$ & \\
\hline 1 & $\alpha$-Pinene & 923 & 5.42 & 22.47 & $\begin{array}{c}4.27 \\
(4.44)^{a}\end{array}$ & 4.071 & 1.928 & 7.70 & 1.05 \\
\hline 2 & $\beta$-Pinene & 962 & 6.38 & 2.07 & $\begin{array}{c}4.35 \\
(4.16)^{a}\end{array}$ & 7.061 & 1.642 & 6.00 & 0.81 \\
\hline 3 & $\alpha$-Fenchyl acetate & 1136 & 10.79 & 2.35 & 3.86 & 23.230 & 6.322 & 13.00 & 2.64 \\
\hline 4 & (-)Bornyl acetate & 1236 & 13.21 & 5.61 & $\begin{array}{c}3.86 \\
(4.30)^{a}\end{array}$ & 42.514 & 2.316 & 22.00 & 4.28 \\
\hline 5 & $\gamma$-Elemene & 1243 & 13.37 & 6.79 & 7.09 & 0.575 & 0.005 & 18.00 & 3.71 \\
\hline 6 & $\alpha$-Copaene & 1314 & 14.96 & 9.84 & 5.71 & 0.161 & 0.086 & 12.00 & 2.47 \\
\hline 7 & trans-Caryophyllene & 1351 & 15.81 & 18.05 & 1.54 & 302.6 & 40.5874 & 7.80 & 0.94 \\
\hline 8 & Valencene & 1366 & 16.16 & 1.81 & 6.30 & 0.543 & 0.026 & 13.00 & 2.56 \\
\hline 9 & $\alpha$-Humulene & 1378 & 16.44 & 1.15 & 6.95 & 0.014 & 0.013 & 15.00 & 3.13 \\
\hline 10 & $\alpha$-Amorphene & 1394 & 16.81 & 3.84 & 6.19 & 0.512 & 0.033 & 11.00 & 2.30 \\
\hline 11 & $\beta$-Maaliene & 1411 & 17.18 & 1.14 & 6.21 & 0.067 & 0.031 & 17.00 & 3.41 \\
\hline 12 & Germacrene-D & 1426 & 17.50 & 0.85 & 6.99 & 0.819 & 0.006 & 18.00 & 3.68 \\
\hline 13 & $\delta$-Cadinene & 1433 & 17.63 & 6.13 & 6.32 & 0.808 & 0.025 & 12.00 & 2.38 \\
\hline 14 & unknown & 1523 & 19.51 & 2.97 & - & - & - & - & - \\
\hline 15 & $\beta$-Eudesmol & 1542 & 19.87 & 14.92 & 4.88 & 7.289 & 0.496 & 29.00 & 6.46 \\
\hline
\end{tabular}

* Kovats index ** Retention time (min.) ${ }^{a}$ The values in parentheses are the experimental values for logarithm of Octanol-Water partitioning coefficients (log$\left.K_{o w}\right)$. The other values were calculated by the EPI-suit v4.00 package. 
Cadinene (6.13\%), (-) Bornyl acetate (5.61\%) are located in the second level of the concentration in the essential oil. Although, in accordance with the data in Table 1, some components i.e., $\alpha$-Amorphene (3.84\%), $\alpha$-Fenchyl acetate $(2.35 \%), \beta$-Pinene $(2.07 \%)$, Valencene $(1.81 \%)$, $\alpha$-Humulene $(1.15 \%), \beta$-Maaliene $(1.14 \%)$ and Germacrene-D $(0.85 \%)$ have the medium up to low relative percentages, could see some important compounds with effects like mold and mildew preventive, microscopy, preservative and antioxidant. Biological and aroma effects of the main and minor compounds of the essential oil of Hymenocrater longiflorus Benth. are discussable in terms of their possible use in medicine, cosmetics and foods.

$\alpha$-Pinene has the highest percentage $(22.47 \%)$ in this herb. $\alpha$-Pinene, is a natural bicyclic sesquiterpene that is a constituent of many essential oils. $\alpha$-Pinene and $\beta$ Pinene. As the name suggests, both forms are important constituents of pine resin; they are also found in the resins of many other conifers, and more widely in other plants. Both are also used by many insects in their chemical communication system. $\alpha$-Pinene and $\beta$-pinene are both produced from geranyl pyrophosphate, via cyclisation of linaloyl pyrophosphate followed by loss of a proton from the carbocation equivalent [12].

$\beta$-Pinene with $12.06 \%$ in this herb was utilized as an intermediate for perfumes and flavorings. It also occurs naturally in rosemary, parsley, dill, basil, yarrow, and rose. $\alpha$-Pinene with $9.94 \%$ in this herb was utilized as solvent for protective coatings, polishes and waxes, synthesis of camphene, comphor, geraniol, terpin hydrate, terpineol, synthetic pine oil, terpene esters and ethers, lube oil additives, flavoring and odorant. It is also found in the essential oil of rosemary (Rosmarinus officinalis).

$\beta$-Caryophyllene or trans-Caryophyllene is one of the chemical compounds that contribute to the spiciness of black pepper. $\beta$-Caryophyllene, is a natural bicyclic sesquiterpene that is a constituent of many essential oils, especially clove oil, the oil from the stems and flowers of Syzygium aromaticum (cloves), the essential oil of hemp Cannabis sativa, and rosemary Rosmarinus oficinalis. It is usually found as a mixture with isocaryophyllene and $\alpha$-humulene, a ring-opened isomer. Caryophyllene is notable for having a cyclobutane ring, a rarity in nature $[12,13]$.

It was found that $\beta$-eudesmol, a sesquiterpenol constituent of Chinese herb antagonized organophosphateinduced lethal toxicity by reversing the neuromuscular failure and reducing the occurrence of convulsions [13].

Its possible antiepileptic action was further explored in electroshock seizure mice in vivo and in high potassium treated rat hippocampal slices in vitro. At a dose with little effect on the motor activity, $\beta$-eudesmol pre- vented the convulsions and lethality induced by maximal electroshock but not those by pentylenetetrazol or picrotoxin. At sub effective doses, $\beta$-eudesmol and phenytoin showed additive effect in preventing electroshock seizures. Extracellular recording of field potentials in CA1 pyramidal layer of hippocampal slices showed that $\beta$-eudesmol reduced the high potassium $(8.5 \mu \mathrm{M})$-induced electrographic seizure activity. The potential of $\beta$-eudesmol to serve as an antiepileptic or a conjuvant in phenytoin therapy is suggested [14].

$\alpha$-Copaene, a potent attractant for male Mediterranean fruit flies. Ceratitis capitata is found as a minor component in the essential oils of various plant species, including its hosts such as orange, guava, and mango. Despite the specific attraction of male flies and the wide distribution of the compound in host plants, the biological significance of $\alpha$-copaene remains unknown [15]. Chemically, the copaenes are tricyclic sesquiterpenes. The molecules are chiral, and the $\alpha$-copaene enantiomer most commonly found in higher plants exhibits a negative optical rotation of about $-6^{\circ}$. The rare $(+)-\alpha$-copaene is also found in small amounts in some plants. It is of economic significance because it is strongly attracting to an agricultural pest, the Mediterranean fruit fly Ceratitis capitata [15]. Bornyl acetate is a constituent of some essential oils. It has been used in aromatic preparations in the treatment of coughs.

Chemically, the cadinenes are bicyclic sesquiterpenes. The term "cadinene" has sometimes been used in a broad sense to refer to any sesquiterpene with the socalled cadalane (4-isopropyl-1, 6-dimethyldecahydronaphthalene) carbon skeleton. Because of the large number of known double-bond and stereochemical isomers, this class of compounds has been subdivided into four subclasses based on the relative stereochemistry at the isopropyl group and the two bridgehead carbon atoms. [13-15].

The acid-catalyzed cyclization of Germacrene-D to give cadinane and selinane sesquiterpenes has been computationally investigated using both density functional (B3LYP/6-31G*) and post Hartree-Fock (MP2/6$31 \mathrm{G}^{* *}$ ) ab initio methods by Setzer in 2008 [16]. It is generally observed that essential oils containing large concentrations of the sesquiterpene germacrene D are typically accompanied by cadinane and muurolane sesquiterpenoids [16-22] and germacrene-D has been suggested to serve as biogenetic precursor to a number of different sesquiterpenoid skeletons [16,23,24]. Bülow and König have demonstrated that germacrene-D readily undergoes acid-catalyzed cyclization to give cadinane, muurolane, and amorphane sesquiterpenes [16,25]. In addition, there is concern that skeletal rearrangements may occur during the hydrodistillation of plant materials 
to obtain essential oils [16,26-29]. Bülow and König $[16,24]$ had found that acid-catalyzed cyclizations of germacrene D generally give a preponderance of $\delta$-cadinene, followed by $\gamma$-cadinene, and lesser amounts of $\alpha$ cadinene. The abundant $\delta$-cadinene is consistent with the $a b$ initio calculations, but the calculated energies of $\alpha$ cadinene and $\gamma$-cadinene are not in agreement with the experimental results, and would predict $\alpha$-cadinene to be more abundant than $\gamma$-cadinene. In addition, $\gamma$-cadinene is more abundant in these essential oils than $\alpha$-cadinene. $\alpha$-Cadinene has been shown to undergo acid-catalyzed rearrangement to give $\beta$-cadinene $[16,30]$, which in turn, has been found to isomerize to $\omega$-cadinene [16,30-32], in agreement with the calculated energies; $\beta$-cadinene and $\omega$-cadinene are lower in energy than $\alpha$-cadinene by 1.88 $\mathrm{kcal} / \mathrm{mole}$ and $2.90 \mathrm{kcal} / \mathrm{mol}$, respectively. Bülow and König [16,24] reported that $\omega$-cadinene can be formed from $\delta$-cadinene in a 1.4:1 ratio, consistent with the nearly equal calculated energies.

It is reported and accepted that the toxicity property of organic compounds can be predicted on the basis of the $\log K_{o w}$ [7]. Total biodegradation $\left(T B_{d}\right)$ is another useful and important factors in chemical and biochemical studies [33]. The $\mathrm{LC}_{50}$ value is called the median lethal concentration and lethal concentration 50 , this value gives an idea of the relative acute toxicity of an in halable material. One of the other important physicochemical factors of compounds is water solubility $\left(S_{w}, \mathrm{mg} . \mathrm{L}^{-1}\right.$ at $25^{\circ} \mathrm{C}$ ). In accordance with the calculated data of the components 1-15 (see Table 1) $\gamma$-Elemene, Germacrene-D and $\alpha$-Humulene have the highest $\log K_{\text {ow }}$, among the components 1-15 (7.09, 6.99 and 6.95, respectively). $\alpha$-Humulene and $\alpha$-Copaene have the lowest water solubility $\left(S_{w}, \mathrm{mg} . \mathrm{L}^{-1}\right.$ at $\left.25^{\circ} \mathrm{C}\right) . \beta$-Caryophyllene has the highest $\mathrm{LC}_{50}(\mathrm{mg} / \mathrm{L})$ and $\gamma$-Elemene, Germacrene-D and $\alpha$-Humulene are three components with lowest $\mathrm{LC}_{50}$ $(0.005,0.006$ and 0.013 , respectively). The total biodegradation $\left(T B_{d}\right)$ of $\beta$-Eudesmol among $1-15$ is the highest and for $\beta$-Pinene is the lowest amount (in $\mathrm{mol} / \mathrm{h}$ and $\mathrm{gr} / \mathrm{h})$. The total biodegradation $\left(T B_{d}\right)$ for $\alpha$-Pinene $(22.47 \%)$ (The highest percentage component) is calculated: $7.70(\mathrm{~mol} / \mathrm{h})$ and $1.05(\mathrm{gr} / \mathrm{h})$. In Table 1, the values in parentheses are the experimental values for logarithm of Octanol-Water partitioning coefficients (log $\left.K_{o w}\right)$. The other values were calculated by the EPI-suit v 4.00 package. For the other items there were not available values from data base [11].

Perhaps, the high densities of the main compounds give some biological activities to the essential oil or to this herb. Although no records of toxicity have been found for this plant, it belongs to a family that includes many poisonous plants so some caution is advised [34,35].

\section{CONCLUSIONS}

Hymenocrater longiflorus Benth., one of the Hymenocrater genus, was collected from Kurdistan area in Iran. It is utilized as the medicinal herb for the various purposes in local and traditional medicine by folks in Kurdistan-Iran. Fifteen components in the essential oil of Hymenocrater longiflorus Benth. representing fourteen of the total oil were identified by GC and GC/MS technique. In this herb, $\alpha$-Pinene, trans-Caryophyllene $(\beta$ Caryophyllene) and $\beta$-Eudesmol have the most percentages among compounds of the essential oil. Some other components $\alpha$-Copaene $(9.84 \%), \gamma$-Elemene $(6.79 \%), \delta$ Cadinene $(6.13 \%),(-)$ Bornyl acetate $(5.61 \%)$ are located in the second level of the concentration in the essential oil. $\alpha$-Amorphene (3.84\%), $\alpha$-Fenchyl acetate (2.35\%), $\beta$-Pinene (2.07\%), Valencene $(1.81 \%), \alpha-\mathrm{Hu}-$ mulene $(1.15 \%), \beta$-Maaliene $(1.14 \%)$ and Germacrene$\mathrm{D}(0.85 \%)$ have the medium up to low relative percentages among 1-15. Some of the other physicochemical data, i.e. octanol-Water partitioning coefficients (log $K_{o w}$ ), the total biodegradation $T B_{d}$ (in $\mathrm{mol} / \mathrm{h}$ and $\mathrm{g} / \mathrm{h}$ ), water solubility $\left(S_{w}, \mathrm{mg} . \mathrm{L}^{-1}\right.$ at $\left.25^{\circ} \mathrm{C}\right)$ and median lethal concentration $50\left(\mathrm{LC}_{50}\right)$ were calculated by the EPI-suit v4.00 package.

\section{ACKNOWLEDGEMENTS}

The authors gratefully acknowledge the colleagues in Chemistry Department of The University of Queensland-Australia, for their useful suggestions. We are also thankful from the Research Council of Science and Research Campus of Islamic Azad University and Arak branch of I. A. University.

\section{REFERENCES}

[1] Schönbeck-Temesy, E. (1992) Wien in K. H. Rechinger, Flora Iranica, Akademische Druck und Verlagsanstalt. Auersperggasse, 12, A 8010 Graz., Austria.

[2] Ebrahimzadeh, H., Radjabian, T., Ekhteraei-Tousi, S., Niknam, V. and Mozafarian, V. (2008) Evaluation of some Iranian wild species from valerianaceae as commercial sources of valepotriates. Journal of Biological Sciences, 8, 549-555. doi: $10.3923 /$ ibs. 2008.549 .555

[3] Hansch, C., Leo, A. and Hoekman, D. (1995) Exploring QSAR: Hydrophobic, electronic, steric constants. ACS, Washington, DC

[4] Bundy, J.G., Morriss, A.W.J., Durham, D.G., Campbell, C. D. and Paton, G.I. (2001) Chemosphere, 42, 885-892. doi:10.1016/S0045-6535(00)00178-8

[5] Li, A. and Yalkowsky, S.H. (1998) Solubility ratio and solute log K-ow. Industrial and Engineering Chemistry Research, 37, 4470-4475. doi:10.1021/ie980232v

[6] Degner, P., Nendza, M. and Klein, W. (1991) Predictive QSAR models for estimating biodegradation of aromatic compounds. Science of the Total Environment, 109, 253259. doi:10.1016/0048-9697(91)90182-E

[7] Cronin, M.T.D. and Dearden, J.C. (1995) Prediction of 
aquatic toxicity. Quantitative Structure Activity Relationships, 14, 1-7.

doi:10.1002/qsar.19950140102

[8] Adams, R.P. (1995) Identification of essential oil components by gas chromatography/mass spectroscopy. Allured Publishing Corporation, Illinoise.

[9] Parker, J.B. (1974) (MOD (PE), Aldemaston), eight pick index of mass spectra. 2nd Edition, Mass Spectroscopy Data Center, Reading.

[10] Hocking, G.M. (1992) Dictionary of natural product. Chapman \& Hall, U.K.

[11] For study about the EPI-suit v4.00. Environmental Protection Agency. http://www.epa.gov/epahome/docs

[12] Mann, J., Davidson, R.S., Hobbs, J.B., Banthorpe, D.V. and Harborne, J.B. (1994) Natural products. Addison Wesley Longman Ltd., Harlow.

[13] Chiou, L.C., Ling, J.Y. and Chang, C.C. (1997) Chinese herb constituent $\beta$-eudesmol alleviated the electroshock seizures in mice and electrographic seizures in rat hippocampal slices. Neuroscience Letters, 231, 171-174. doi:10.1016/S0304-3940(97)00557-0

[14] Nishida, R., Shelly, T.E., Whittier, T.S. and Kanshiro, K. Y. (2000) $\alpha$-Copaene, a potential rendezvous cue for the mediterranean fruit fly, Ceratitis capitata. Journal of Chemical Ecology, 26, 87-100. doi:10.1023/A:1005489411397

[15] Nishida, R., et al. (2000) Alpha-copaene, a potential rendezvous cue for the mediterranean fruit fly, Ceratitis capitata? Journal of Chemical Ecology, 26, 87. doi:10.1023/A:1005489411397

[16] Setzer, W.N. (2008) Germacrene D Cyclization: An Ab Initio Investigation. International Journal of Molecular Sciences, 9, 89-97. doi:10.3390/ijms9010089

[17] Setzer, W.N. and Haber, W.A. (2007) Leaf essential oil composition of five species of Beilschmiedia from Monteverde, Costa Rica. Natural Product Communications, 2, 79-83.

[18] Eason, H.M. and Setzer, W.N. (2007) Bark essential oil composition of Cedrela tonduzii C. DC. (Meliaceae) from Monteverde, Costa Rica. Records of Natural Products, 1, 24-27.

[19] Setzer, W.N. (2006) Chemical compositions of the bark essential oils of Croton monteverdensis and Croton niveus from Monteverde, Costa Rica. Natural Product Communications, 1, 567-572.

[20] Cole, R.A., Haber, W.A. and Setzer, W.N. (2007) Chemical composition of essential oils of seven species of Eugenia from Monteverde, Costa Rica. Biochemical Systematics and Ecology, 35, 877-886. doi:10.1016/i.bse.2007.02.003

[21] Takaku, S., Haber, W.A. and Setzer, W.N. (2007) Leaf essential oil composition of 10 species of Ocotea (Lauraceae) from Monteverde, Costa Rica. Biochemical Systematics and Ecology, 35, 525-532.

[22] Setzer, W.N., Park, G., Agius, B.R., Stokes, S.L., Walker, T.M., Haber, W.A. (2008) Chemical compositions and biological activities of leaf essential oils of twelve species of Piper from Monteverde, Costa Rica. Molecules,
13.

[23] Yoshihara, K., Ohta, Y., Sakai, T. and Hirose, Y. (1969) Germacrene D, a key intermediate of cadinene group compounds and bourbonenes. Tetrahedron Letter, 2263-2264. doi:10.1016/S0040-4039(01)88136-3

[24] Bülow, N. and König, W.A. (2000) The role of germacrene $\mathrm{D}$ as a precursor in sesquiterpene biosynthesis: investigations of acid catalyzed, photochemically and thermally induced rearrangements. Phytochemistry, 55, 141-168. doi:10.1016/S0031-9422(00)00266-1

[25] Bartley, J.P. and Foley, P. (1994) Supercritical fluid extraction of Australian-grown ginger (Zingiber officinale) Journal of the Science of Food and Agriculture, 66, 365-371. doi:10.1002/jsfa.2740660314

[26] Asfaw, N., Storesund, H.J., Skattebøl, L. and Aasen, A.J. (2001) Coexistence of chrysanthenone, filifolone, and (Z)-isogeranic acid in hydrodistillates. Artefacts, Phytochemistry, 58, 489-492. doi:10.1016/S0031-9422(01)00254-0

[27] Babu, K.G.D. and Kaul, V.K. (2005) Variation in essential oil composition of rose-scented geranium (Pelargonium sp.) distilled by different distillation techniques. Flavour and Fragrance Journal, 20, 222-231. doi:10.1002/ffj.1414

[28] Teixeira, S., Mendes, A., Alves, A. and Santos, L. (2007) Simultaneous distillation-extraction of high-value volatile compounds from Cistus ladanifer L.. Analytica Chimica Acta, 584, 439-446. doi:10.1016/j.aca.2006.11.054

[29] Fringuelli, F., Pizzo, F., Taticchi, A., Ferreira, V.F., Michelotti, E.L., Porter, B. and Wenkert, E. (1985) Diels-Alder reactions of cycloalkenones. 4. Short syntheses of some cadinenes. Journal of Organic Chemistry, 50, 890-891. doi:10.1021/jo00206a036

[30] Vlahov, R., Holub, M. and Herout, V. (1967) On terpenes. CLXXXIV. Sesquiterpenic hydrocarbons from the essential oil of Mentha piperita of Bulgarian origin. Collection of Czechoslovak Chemical Communications, 32, 822-829.

[31] Connell, D.W., Hildebrand, R.P. and Sutherland, M.D. (1968) Terpenoid chemistry XIV: The significance of the term $\delta$-cadinene. Tetrahedron Letter, 519-523. doi:10.1016/S0040-4039(01)98796-9

[32] Nagasampagi, B.A., Yankov, L. and Dev, S. (1968) Sesquiterpenoids from the wood of Cedrela toona Roxb partial synthesis of T-muurolol, T-cadinol and cubenol, structures of $\delta$-cadinene and $\delta$-cadinol. Tetrahedron Letter, 1913-1918.

[33] Bundy, J.G., Morriss, A.W.J., Durham, D.G., Campbell, C. D. and Paton, G.I. (2001) Chemosphere, 42, 885-892. doi:10.1016/S0045-6535(00)00178-8

[34] (1992) Dictionary of natural product. Chapman \& Hall, U.K.

[35] Hawley, G.G. (1997) Condensed chemical dictionary. 13th Edition, Van Nostrand Reinhold Company Inc. New York. 